\title{
The Changing Governance of Welfare: Recent Trends in its Primary Functions,
}

Scale, and Modes of Coordination

\section{Bob Jessop}

My main focus, as requested by the editors, is the changing governance of welfare. But changes in this regard are inseparable from broader changes in the welfare regimes that emerged in advanced western capitalist states in the postwar Atlantic Fordist boom. Thus I will also discuss the social and economic functions that current welfare regimes are expected to perform and the scales on which these functions are undertaken. My analysis starts from the interest in more or less radical reform of postwar welfare states and relates this to the weakening of their governance structures as well as their policy effectiveness by the interaction of various economic, social, and political factors.

\section{The Keynesian Welfare National State}

A highly provocative claim in this regard comes from Claus Offe, who, writing as issues of crisis, crisis-management, and crisis resolution moved up the political agenda, argued that 'while capitalism cannot coexist with, neither can it exist without, the welfare state' (1984: 153, italics in original). My concluding comments suggest a solution to 'Offe's paradox'. But this first requires a new analysis of welfare regimes going beyond what Offe and his neo-marxist contemporaries, for all their acuity, could offer fifteen years ago, before the crises in and/or of welfare regimes had developed to the present extent (for a general critique of their position, see Klein 1993). Thus, building on the French regulation approach to political economy and recent institutionalist work on governance, I discuss the role of welfare regimes in economic and social reproduction, the scales on which welfare is organized, and the forms deployed in governing them.

An important step in clarifying Offe's paradox is to identify the form of welfare state said to be in crisis. This is the form that became dominant in North Western Europe, North America, Australia, and New Zealand during the 1950s to 1970s and that was closely linked with the Fordist growth dynamic. It can be described in ideal-typical terms as the Keynesian welfare national state (or KWNS). Each term in this fourfold construct highlights its distinctive features and ignores any generic properties the 
KWNS may share with other types of capitalist welfare regime. Thus, before presenting this ideal type, I justify the criteria used in constructing it and will thereby highlight some general features of capitalist economic and social reproduction.

The four criteria derive from features of capitalism as a mode of production. The first criterion is the state's distinctive roles in securing conditions for profitable private business. This is the broad field of economic policy. It is important because market forces alone cannot secure these conditions and are supplemented by non-market mechanisms. This insufficiency is grounded in generic tendencies towards market failure and in specific contradictions and dilemmas associated with capitalism. The second dimension refers to the state's distinctive roles in reproducing labour power individually and collectively over various timespans from quotidian routines via individual lifecycles to intergenerational reproduction (on lifecycles, see Falkingham and Hills 1995). This is the broad field of social policy. It matters because labour power is a fictitious commodity (Polanyi 1944; Brunhoff 1968). For, although it is bought and sold in labour markets and may add value in production, it is not itself directly (re)produced in and by capitalist firms with a view to private profit. Labour power enters the market economy from outside and is embodied in individuals who have other identities than as bearers of labour-power. This poses economic problems as regards its individual and collective suitability to capital's needs and its own survival in the absence of a secure income or other assets; social problems regarding social inclusion and cohesion; and political problems regarding the legitimacy of state intervention in this area and its relation to other identities that workers may have. The third dimension refers to the main scale, if any, on which economic and social policies are decided - even if underpinned or implemented on other scales. This is important as economic and social policies are politically mediated and the scales of political organization may not coincide with those of economic and social life. The fourth dimension concerns the relative weight of the mechanisms deployed in the effort to maintain capitalist profitability and reproduce labour-power by compensating for market failures and inadequacies. This is where issues of governance are most relevant - although governance also enters into the other three dimensions. Top-down state intervention is just one of these mechanisms; and, as is well known, states as well as markets can fail. This suggests the need for other supplementary mechanisms and, insofar as these also tend to fail, for attention to the balance among them (Dunsire 1996; Bochel and Bochel 1998). 
I now define the KWNS on these four dimensions. First, in promoting the conditions for capital's profitability, it can be described as distinctively Keynesian insofar as it aimed to secure full employment in a relatively closed national economy and to do so mainly through demand-side management. Second, in reproducing labour-power as a fictitious commodity, KWNS social policy had a distinctive welfare orientation insofar as it tried (a) to generalize norms of mass consumption beyond male workers in Fordist economic sectors earning a family wage so that national citizens and their dependants could all share the fruits of economic growth (and thereby also contribute to effective domestic demand); and (b) to promote forms of collective consumption favourable to the Fordist growth dynamic with its base in a virtuous national circle of mass production and mass consumption. Thus economic and social policies were linked to economic and social rights attached directly or indirectly to citizenship of a national territorial state - whether this citizenship was based on descent, acculturation, naturalization, political tests, or some other criterion (on types of national state, Jessop 1999a). Third, the KWNS was national insofar as economic and social policies were pursued within the historically specific (and socially constructed) matrix of a national economy, a national state, and a society seen as comprising national citizens. Within this matrix it was the national territorial state that was mainly held responsible for developing and guiding Keynesian welfare policies (de Swaan 1992). Local and regional states acted mainly as relays for policies framed at the national level; and the various international regimes established after WW2 were mainly intended to restore stability to national economies and national states. And, fourth, the KWNS was statist insofar as state institutions (on different levels) were the chief supplement to market forces in securing the conditions for economic growth and social cohesion. It was the combination of market and state on different levels that prompted the use of the term 'mixed economy' to describe the postwar system (classically, Shonfeld 1965). In addition to its role in facilitating and correcting the operation of market forces, the state also had a dominant role in shaping civil society and thus the identities held by its citizens.

There was never a pure form of KWNS. At best one finds particular welfare regimes that combine the four features of the KWNS (in one or other of its variant forms) with other functions, scales of action, or modes of governance. Nor is there a pure crisis of the KWNS - only specific, path-dependent, nationally variable crises. In some cases there has been greater continuity, linked to the dominance of the view that 
there was a crisis in the welfare state, with largely incremental shifts towards the new welfare regime (e.g., Denmark); in others there has been greater discontinuity admittedly more marked in declared policy changes than actual policy outcomes linked to a discursively-constructed crisis of the welfare state (e.g., Britain).

\section{The Importance of Governance}

For present purposes 'governance' refers to any form of coordination of interdependent social relations - ranging from simple dyadic interactions to complex social divisions of labour. Three main forms of coordination are usually distinguished: the anarchy of exchange (e.g., market forces), the hierarchy of command (e.g., imperative coordination by the state), and the 'heterarchy' of self-organization (e.g., networks). Along with other commentators I refer to the third form of coordination as 'governance in the narrow sense' in contrast to the broader concept that also encompasses market forces and organizational hierarchies (on governance and governance failure, see Jessop 1998; also Kooiman 1993; Dunsire 1996).

With the development of formally free labour markets, market forces became the chief mode of capitalist economic coordination. But the invisible hand, with its formal monetary maximands, impersonality (working, as Marx put it, behind the backs of the producers), procedural rationality, and post hoc operation, is supplemented through other modes of coordination that introduce more substantive objectives, elements of interpersonal or interorganizational deliberation, orientation to collective goals, and ex ante concertation. It is in this context that welfare regimes can help to secure some of the key conditions for capital accumulation. For they are implicated in governing the economic, gender, ethnic, intergenerational (and many other) aspects of the division of labour - and indeed themselves contribute to the 'labour of division', i.e., the classification and normalization of individuals, groups, and other social forces as a basis for differential treatment in the division of labour and for social inclusion-exclusion (on the labour of division, Munro 1997). The concept of governance is very useful in analyzing welfare regimes as it enables us to classify regimes in terms of their typical combinations of modes of coordination. The concept of the 'mixed economy of welfare' (Titmuss 1963; Pinker 1992) captures aspects of this; but, because it focuses on mechanisms of redistribution (occupational, fiscal, 
welfare benefits), it neglects the ways that welfare regimes govern production and reproduction more generally.

In this light one might consider three interrelated issues in the governance of welfare. These are the changing definitions of welfare; the changing institutions responsible for its delivery; and the practices in and through which welfare is delivered. These issues are closely linked. For it is a social scientific commonplace that governance practices (mediated by institutions) attempt to delimit, unify, stabilize and reproduce their objects of governance as the precondition as well as the effect of governing them. Moreover, as recent Foucauldian analyses have emphasized, governance practices also typically aim to create and reproduce the subjects needed for governance to operate effectively (Barry et al., 1996; Hunt and Wickham 1993). Thus, as the objects and modes of governance change, institutional mechanisms and actual practices change too - and so do the typical forms of governance failure. In this sense we should see welfare regimes as constitutive of their objects of governance and not just as responses to pre-given economic and social problems. Indeed this is one of the bases on which the welfare state is often criticized - that it generates the problems it addresses. This also suggests that it will be self-expanding - always finding new problems to solve - and, perhaps, ultimately self-defeating as it becomes more complex, overloads itself with tasks, and eventually produces a crisis of ungovernability (e.g., Crozier et al., 1975).

Whether or not one subscribes to such criticisms, it was the purported failure of the KWNS as a mode of economic and social governance that prompted the search for new forms of governance. Its alleged crisis affected not only the modes of 'governance-government-governing' in the KWNS but also its objects and subjects of social and economic governance. More specifically, the KWNS began to fail as a mode of governance when its coherence as an institutional ensemble became inconsistent with the objects it was governing, the practices being deployed to govern them, and the identities and interests of the active agents and/or 'passive' subjects of the KWNS regime. Thus, taking its four dimensions in turn, I would identify the following crisis-tendencies.

First, the primary object of economic governance in the KWNS was the national economy. The emergence and consolidation of Keynesian practices had helped to delimit and reproduce the national economy (Tomlinson 1985). They provided the means of measuring national economic performance, controlling economic flows 
across national borders, setting economic aggregates such as inflation, employment, and growth as goals of national economic management, and creating the infrastructure for national economic development. But Keynesian economic management became increasingly problematic and generated stagflationary tendencies (stagnation plus inflation) that fuelled the emerging crisis of the Atlantic Fordist economy that the KWNS was supposed to manage (Boyer 1991). Economic internationalization exacerbated these problems. It undermined the national economy as an object of economic management and led to quite different conceptions of the economy and, a fortiori, its mechanisms of economic and social governance. States could no longer act as if national economies were more or less closed and their growth dynamics were primarily domestic (Teeple 1995). Replacing the national economy as the primary object of economic governance is the knowledge-driven economy in an era of globalization (Castells 1996). Its growth dynamic depends on how effectively a given economic space - not necessarily a national economy - is inserted into the changing global division of labour. This in turn has prompted concern with international economic competitiveness and supplyside intervention - initially to supplement national demand management, later as the primary objective and means of economic intervention.

The imagined scope and inclusiveness of the economy that needs governing have also expanded. This is no longer interpreted in narrow terms but has been extended to include many additional factors, deemed 'non-economic' under the KWNS regime, that affect economic performance. This expansion is reflected in concepts such as 'structural competitiveness' (Chesnais 1986) or 'systemic competitiveness' (Messner 1997) - concepts that highlight the combined impact of diverse societal factors on competitiveness. State managers therefore intervene in a growing range of economically relevant practices, institutions, functional systems, and domains of the lifeworld to enhance competitiveness. This has two interesting and paradoxical effects on the state. First, whilst it expands the potential scope of state intervention for economic purposes, the resulting complexity renders postwar top-down intervention less effective - requiring that the state retreat from some areas of intervention and re-invent itself as a condition for more effective intervention in others (Messner 1997). And, second, whilst it increases the range of stakeholders whose cooperation is required for successful state intervention, it also increases pressures within the state to create new subjects to act as its partners. Thus states 
are now trying to transform the identities, interests, capacities, rights, and responsibilities of economic and social forces so that they become more flexible, capable, and reliable agents of the state's new economic strategies - whether in partnership with the state and/or with each other or as autonomous entrepreneurial subjects in the new knowledge-driven economy (Barry et al., 1996; Deakin and Edwards 1993; Finer 1997; Jones 1999).

Second, the generic object of social governance in the KWNS (as in other forms of national state) was a national population divided in the first instance into citizens of the national state and resident aliens. But this population was categorized and governed in distinctive ways suited to Atlantic Fordism and its mode of regulation. Above all, social policy was premised on conditions of full or near-full employment, lifelong employment - albeit not necessarily with the same employer - with a family wage for male workers, and the patriarchal nuclear family as the basic unit of civil society (Esping-Andersen 1994). The KWNS was also premised on a class compromise between organized labour and organized business in which responsible unionism and collective bargaining permitted managers to manage and workers to benefit from rising productivity as wage earners and welfare recipients. There were nonetheless some marginalized or overburdened social groups - most notably women as housewives, mothers, and secondary participants in the labour force and also immigrants or other workers (and their families) who worked in disadvantaged segments of the labour market (Lewis 1998). This pattern was undermined both economically and socially. The crisis of Atlantic Fordism undermined the assumptions of full employment, the family wage, and the gendered division of labour; and also led state managers to see the social wage increasingly as a cost of international production rather than as a source of domestic demand. The KWNS was also affected by a weakening of the national identity and solidarity that shaped it in its formative period and helped sustain the coalition behind it. This is reflected in changes in the values, social identities, and interests associated with the welfare state. Indicators of this included rejection of the social democratic and/or Atlantic Fordist commitment to a class-based redistributive politics; a pluralistic identity politics and 'politics of difference' that emphasizes mutual respect, authenticity, and autonomy; increased concern for personal empowerment rather than for the bureaucratic administration of legal rights, monetized entitlements, and uniform public services; and expansion of the so-called 'third' sector, which supposedly 
operates flexibly outside of the framework of pure markets and the bureaucratic state (but often in close conjunction with them as a 'shadow market' and 'shadow state'). These shifts have fragmented the KWNS coalition of forces, led to demands for more differentiated and flexible forms of economic and social policy, and led to concern with problems of social exclusion and ensuring life-time access to the benefits of a restructured welfare regime (e.g., lifelong learning).

Third, the primacy of the national scale of economic and social governance depended on the coincidence of national economy, national state, national society and the survival of the national state as a sovereign body. This structured coherence has also been weakened. The national economy has been undermined by internationalization, the growth of multi-tiered global city networks, the formation of triad economies (such as the European Union), and the re-emergence of regional and local economies in national states. This complex articulation of global-regionalnational-local economies is related to the 'hollowing out' of the national state as its powers are delegated upwards to supra-regional or international bodies, downwards to regional or local states, or outwards to relatively autonomous cross-national alliances among local metropolitan or regional states with complementary interests. There are also growing attempts to internationalize (or, at least, Europeanize) social policy. And, third, the unity of the nation-state has been weakened by the (admittedly uneven) growth of multi-ethnic and multi-cultural societies and of divided political loyalties (with the resurgence of regionalism and nationalism as the rise of European identities, diasporic networks, cosmopolitan patriotism, etc.) (Jessop 1999a). Thus we see a proliferation of scales on which economic and social policy are pursued as well as competing projects to re-unify inter-scalar articulation around a new primary level - whether this be the industrial district, the city-region, wider sub-national regions, cross-border regions, the triads, or the global level.

Finally, the state's role in the mixed economy was undermined by several factors. These include: growing political resistance to taxation and the emerging stagnationinflation; crisis in postwar compromises between industrial capital and organized labour; new economic and social conditions and attendant problems that cannot be managed or resolved readily, if at all, through continuing reliance on top-down state planning and/or simple market forces; growing resentment about the bureaucratism, inflexibility, and cost of the welfare state as it continued to expand during the late 1960s and 1970s; and the rise of new social movements which did not fit easily into 
the postwar compromise. Moreover, as society has become more complex and as new economic and social conditions emerge that cannot be managed or resolved readily, if at all, through the market and state as modes of governance, there has been increasing reliance on networks and partnerships as modes of coordination. Organizationally the Fordist period was one of large scale, top-down hierarchical structures and this model spread to the state's economic and welfare roles. This paradigm is being challenged by a new 'network paradigm' that emphasizes partnership, regulated self-regulation, the informal sector, the facilitation of selforganization, and decentralized context-steering (Messner 1997). Overall this involves a tendential shift from imperative coordination by the sovereign state to an emphasis on interdependence, divisions of knowledge, reflexive negotiation, and mutual learning. In short, there is a shift from government to governance in the narrow sense.

\section{The Schumpeterian Workfare Postnational Regime}

These changes are reflected in four general trends in the restructuring of the KWNS. The first is a shift from Keynesian aims and modes of intervention to Schumpeterian ones; the second is a shift from a welfarist mode of reproduction of labour-power to a workfarist mode; the third is a shift from the primacy of the national scale to a postnational framework in which no scale is predominant; the fourth is a shift from the primacy of the state in compensating for market failures to an emphasis on networked, partnership-based economic, political, and social governance mechanisms. These trends can be considered separately. Indeed, both severally and in combination, they have developed in quite different ways in the various Atlantic Fordist economies. They can nonetheless be summarized in terms of the suggestion that the Keynesian welfare national state (KWNS) is giving way to a Schumpeterian workfare post-national regime (SWPR). Moreover, whether viewed individually or in aggregate, these four changes are closely connected to the search for solutions to the Atlantic Fordist crisis.

The ideal-typical SWPR can be described as follows. First, regarding its functions for capital, it is Schumpeterian insofar as it tries to promote permanent innovation and flexibility in relatively open economies by intervening on the supply-side and to strengthen as far as possible their structural and/or systemic competitiveness. 
Complementing these new strategic concerns in economic and social policy has been the demotion or rejection of other, earlier policy objectives. Whilst the KWNS aimed to secure full employment, the SWPR demotes this aim in favour of promoting structural or systemic competitiveness. Second, regarding social reproduction, the SWPR can be described (at the risk of misunderstanding) as a workfare regime insofar as it subordinates social policy to the demands of labour market flexibility and employability and to the demands of structural or systemic competitiveness. Thus, whilst the KWNS tried to extend the social rights of its citizens, the SWPR is concerned to provide welfare services that benefit business and thereby demote individual needs to second place. This includes putting downward pressure on the social wage qua cost of international production. Concern with training and labour market functioning has long been a feature of state involvement in the social reproduction of labour-power, of course, but the SWPR gives greater weight to flexibility and endows it with new connotations (Ainley 1997). It is for these reasons that there is also a major reorientation on the part of the state to the making and remaking of the subjects who are expected to serve as partners in the innovative, knowledge-driven, entrepreneurial, flexible economy and its accompanying selfreliant, autonomous, empowered workfare regime (for a recent illustration, Blair and Schröder 1999).

Third, compared with the earlier primacy of the national scale, the SWPR is 'postnational' insofar as the increased significance of other spatial scales and horizons of action (or 'relativization of scale') ${ }^{1}$ makes the national territory less important as a 'power container'. This is associated with a transfer of economic and social policy-making functions upwards, downwards, and sideways. International agencies (such as the IMF, World Bank, OECD, and ILO) play an increased role in shaping the social as well as economic policy agendas; in Europe, moreover, the European Union also has a growing role (cf. de Swaan 1992; Deacon 1995; Leibfried, 1993; Wilding 1997). But there is a simultaneous devolution of some economic and social policy-making to the regional, urban, and local levels on the grounds that policies intended to influence the micro-economic supply-side and social regeneration are best designed close to their sites of implementation. In some cases this also involves cross-border cooperation among regional, urban, or local spaces. In all three regards welfare governance has become more postnational. Yet, paradoxically, this leads to an enhanced role for national states in controlling the 
interscalar transfer of these powers - suggesting a shift from sovereignty to a primus inter pares role in intergovernmental relations.

Finally, regarding the mode of delivery of economic and social policies, the SWPR has a regime form because of the increased importance of non-state mechanisms in compensating for market failures and inadequacies and in the delivery of statesponsored economic and social policies. This provides a second important aspect to the apparent (but deceptive) 'hollowing out' of national states, namely, the increased importance of private-public networks to state activities on all levels - from local partnerships to supranational neo-corporatist arrangements (e.g., Clarke and Gaile 1998; Falkner 1998).

Like all ideal-types, the SWPR has been formed through the one-sided accentuation of empirically observable features (in this case, in Atlantic Fordist societies) to construct a logically possible social phenomenon. This does not presuppose actual examples of the SWPR in pure form nor imply that any movement along its different dimensions occurs evenly and at the same pace. Indeed there is significant variation in the search for solutions to the alleged problems of the KWNS. It involves neither a unidirectional movement nor a multilateral convergence across all national regimes.

\section{Concluding Remarks}

This article has presented an ideal-typical contrast between two forms of welfare regime - the Keynesian Welfare National State and the Schumpeterian Workfare Postnational Regime. My other work on these two forms deals mainly with their economic and social functions in reproducing private capital and labour-power. This article addresses the governance of welfare regimes and the changing scales on which such governance occurs. It has argued that the national mixed economy of welfare (based on a combination of market and plan) is giving way to a new postnational mixed economy in which networks and partnership have become more important. I have also argued that the subjects as well as the objects of governance are being reconstituted. Since this involves far more than a simple technical fix, it is easy to see why the transition from KWNS to SWPR is always politically mediated and often difficult. Thus, although my entry point for analyzing the transition is inspired by Marxist political economy, a critique of politics is also required. This would serve not only to interpret the political mediations of the transition (as well as 
any 'conservation-dissolution' effects) ${ }^{2}$ but also the constitutive role of politics in defining the problems to which the transition is a response and redefining both the objects and subjects of governance. This in turn helps to explain why, despite a tendential de-nationalization of the state and a shift from government to governance, national states still have major roles in shaping how the economic and social reproduction requirements of capital are met. For they try to determine which functions go upwards, downwards, and sideways and the conditions on which they stay there; and also seek both to design governance mechanisms and to politically organize self-organization.

Space limitations prevented me from identifying sub-types of KWNS and SWPR and from assessing how far the posited changes have occurred in particular cases. But, just as there were different forms of governance in the KWNS, so the SWPR also has variant forms (neo-liberal, neo-corporatist, neo-statist, and, as a supplement, neo-communitarian) (but see Jessop 1993, 1994, 1999b). While there are economic, political, and intellectual forces that are closely identified with one or other mode of governance, these sub-types are best seen as poles around which different national solutions have developed (and are developing) during more or less extended periods of conflict and experimentation. Currently the neo-liberal form of SWPR is hegemonic on the international level but important counter-currents exist in specific national and regional contexts. Each sub-type and each welfare-workfare mix has different implications for welfare policy. The particular mix in individual cases will depend on institutional legacies, the balance of political forces, and the changing economic and political conjunctures in which different strategies are pursued. They will also be overdetermined by factors beyond those included within this particular approach to the political economy of welfare. There is certainly no reason to expect a multilateral convergence of welfare regimes around one sub-type of the SWPR - let alone a rapid convergence.

Finally, I want to suggest a solution to 'Offe's paradox'. On the one hand, capitalism (in its Atlantic Fordist form) did co-exist with the welfare state (in its KWNS form) for an extended period. Eventually the Fordist growth regime and its KWNS mode of regulation became mutually contradictory. This prompted a search for new economic and social bases for capital accumulation; and this involved a partial dismantling of the KWNS. In this sense the emerging post-Fordist capitalist regime cannot co-exist with the KWNS. But this search extends to new forms of state (or, alternatively, 
extra-economic) intervention that might help to re-secure conditions for private profitability and the reproduction of labour-power. One could perhaps label this a simple restructuring of the welfare state but emphasizing policy continuities in this way actually hides as much (if not more) than it reveals (the problem in, for example, Klein's critique, 1993). For the core organizational principles of the KWNS are being superseded in favour of those of the SWPR as a condition for the renewed coexistence of capitalism and the welfare state. Nonetheless this has several possible forms and should not be reduced to the neo-liberal workfare state favoured by Thatcher and Major - and taken as the starting point for New Labour's "Third Way").

\section{Endnotes}

1 On the 'relativization of scale', see Collinge (1996).

2 These effects occur when certain features of an earlier system are retained but acquire a new significance when inserted into an emerging system.

\section{Bibliography}

Ainley, P. (1997) Toward a Learning Society or Towards Learningfare? Social Policy Review 9, 50-68.

Barry, A., Osborne, T., and Rose, N. (1996), Foucault and Political Reason: Liberalism, neo-Liberalism and Rationalities of Government, UCL Press: London. Blair, T. and Schröder, G. (1999), Europe: the Third Way/Die Neue Mitte, http://www.labour.org.uk/views/items/00000053.html

Bochel, C. and Bochel, H. (1998) The Governance of Social Policy, Social Policy Review 10, 57-74.

Boyer, R. (1991), The Eighties: the Search for Alternatives to Fordism, in The Politics of Flexibility, eds, B. Jessop, H. Kastendiek, and K. Nielsen, Edward Elgar: Aldershot: pp. 106-132,

Castells, M. (1996), The Rise of the Network Society, Blackwell: Oxford. 
Chesnais, F. (1986), Science, Technology and Competitiveness, STI Review, 1: 86129.

Clarke, S.E. and Gaile, G.L. (1998), The Work of Cities, University of Minnesota Press: Minneapolis.

Collinge, C. (1996), Spatial Articulation of the State: Reworking Social Relations and Social Regulation Theory. Centre for Urban and Regional Studies: Birmingham.

Crozier, M., Huntington, S.P., and Watanuki, J. (1975), The Crisis of Democracy, New York University Press: New York.

Deacon, B. (1995) The Globalisation of Social Policy and the Socialisation of Global Politics, Social Policy Review 7, 55-76.

Deakin, N. and Edwards, J. (1993), The Enterprise Culture and the Inner City, Routledge: London.

de Brunhoff, S. (1968), The State, Capital and Economic Policy, Pluto Press: London.

de Swaan, A. (1992), Perspectives for Transnational Social Policy, Government and Opposition, 27.1: 33-51.

Dunsire, A. (1996), Tipping the Balance: Autopoiesis and Governance, Administration and Society, 28.3: 299-334.

Esping-Andersen, G. (1994), Equality and Work in the Post-Industrial Life Cycle, in Reinventing the Left, ed., D. Miliband, ed., Polity: Cambridge, pp. 167-185.

Falkingham, J. and Hills, J., eds (1995), The Dynamic of Welfare: the Welfare State and the Life Cycle, Prentice Hall: Hemel Hempstead.

Falkner, G. (1998), EU Social Policy in the 1990s: Towards a Corporatist Policy Community, Routledge: London.

Finer, C.J. (1997), The New Social Policy in Britain, Social Policy \& Administration, 31.5: 154-170.

Munro, R. (1997), Ideas of Difference: Stability, Social Spaces and the Labour of Division, in Ideas of Difference: Social Spaces and the Labour of Division, eds, K. Hetherington and R. Munro, Blackwell: Oxford, pp. 3-26.

Hunt, A. and Wickham, G. (1993), Foucault and Law: Towards a Sociology of Governance, Pluto Press: London.

Jessop, B. (1993), Towards a Schumpeterian Workfare State? Preliminary Remarks on Post-Fordist Political Economy, Studies in Political Economy, 40: 7-39. 
Jessop, B. (1994), The Transition to Post-Fordism and the Schumpeterian Workfare State, in Towards a post-Fordist Welfare State?, eds, R. Burrows and B. Loader, Routledge: London, pp. 13-37.

Jessop, B. (1998), The Rise of Governance and the Risks of Failure: The Case of Economic Development, International Social Science Journal, 155: 29-46.

Jessop, B. (1999a), Narrating the Future of the National Economy and the National State? Remarks on Re-mapping Regulation and Re-inventing Governance, in STATE/CULTURE: State Formation after the Cultural Turn, ed., G. Steinmetz, Cornell University Press: Ithaca, pp. 378-405.

Jessop, B. (1999b), From Keynesianism to Workfarism, in Rethinking Welfare Policy, ed. Gayle Lewis, Milton Keynes: Open University Press (in press).

Jones, M. (1999), New Institutional Spaces: TECs and the Remaking of Economic Governance, Jessica Kingsley Publishers: London.

Klein, R. (1993), O'Goffe's Tale, in New Perspectives on the Welfare State in Europe, ed. C. Jones, Routledge: London, pp. 7-17.

Kooiman, J. ed. (1993), Modern Governance: New Government-Society Interactions, Sage: London.

Leibfried, S. (1993), Toward a European Welfare State, in New Perspectives on the Welfare State in Europe, ed. C. Jones, Routledge: London, pp. 133-156.

Lewis, G. (1998), "Coming apart at the seams": the Crises of the Welfare State, in Unsettling Welfare: the Reconstruction of Social Policy, eds, G. Hughes and G. Lewis, Routledge: Routledge, pp. 39-79.

Messner, D. (1997), The Network Society: Economic Development and International Competitiveness as Problems of Social Governance, Frank Cass: London.

Offe, C. (1984), Contradictions in the Welfare State, Hutchinson: London.

Pinker, R. (1992), Making Sense of the Mixed Economy of Welfare, Social Policy \& Administration, 26.4: 273-284.

Polanyi, K. (1944), The Great Transformation: the Economic and Political Origins of Our Time, Rinehart: New York.

Shonfield, A. (1965), Modern Capitalism, Oxford University Press: Oxford.

Teeple, G. (1995), Globalization and the Decline of Social Reform, Garamont Press: Toronto.

Titmuss, R.M. (1963), Essays on the Welfare State, Allen \& Unwin: London. 
Tomlinson, J. (1985), British Macroeconomic Policy since 1940, Croom Helm: London.

Wilding, P. (1997), Globalization, Regionalization and Social Policy, Social Policy \& Administration, 31.4: 410-428. 